DOI 10.37882/2223-2974.2020.10.09

\title{
ГОСУДАРСТВЕННО-ЧАСТНОЕ ПАРТНЕРСТВО КАК УСЛОВИЕ РАЗВИТИЯ ПРЕДПРИНИМАТЕЛЬСКОЙ ДЕЯТЕЛЬНОСТИ В НАРОДНЫХ ХУДОЖЕСТВЕННЫХ ПРОМЫСЛАХ
}

\section{PUBLIC-PRIVATE PARTNERSHIP AS A CONDITION FOR THE DEVELOPMENT OF ENTREPRENEURSHIP IN THE FIELD OF FOLK ART CRAFTS}

\section{Zhigalova}

Summary: The Implementation of PPP in the field of NHP is a longterm contractual partnership between the public and private sector. This may include the financing, design, construction, operation and/or maintenance of infrastructure and the provision of services by the private sector, which are usually purchased and provided by the public sector. The PPP model provides advantages for both parties, provided that the goals of the public and private sectors are effectively combined. It is important to take into account the circumstances in which PPP may be the best method of developing business activities in the field of NHP compared to other traditional methods of public procurement.

Keywords: entrepreneurship, business activity, public-private partnership, folk arts and crafts, investment, civil law.

\author{
Жигалова Ирина Валерьевна \\ Директор, филиал в г. Нижний Новгород \\ Юридическая форма «Городисский и партнеры» \\ Zhigaloval@gorodissky.ru
}

Аннотация: Реализация ГЧП в НХП представляет собой долгосрочные договорные партнерские отношения между государственным и частным сектором. ГЧП может включать субсидирование, проектирование, строительство, эксплуатацию и/или техническое обслуживание определенных объектов и предоставление услуг частным сектором, которые обычно закупаются и предоставляются государственным сектором. Модель ГЧП дает преимущества для обеих сторон при условии эффективного сочетания целей государственного и частного секторов. Важно учитывать обстоятельства, при которых ГЧП может быть наилучшим методом развития предпринимательской деятельности в отрасли НХП по сравнению с другими традиционными методами государственных закупок.

Ключевые слова: предпринимательство, предпринимательская деятельность, государственно-частное партнерство, народные художественные промыслы, инвестиции, гражданское право.

Создается ожидание, что частный капитал должен быть мобилизован для заполнения этих пробелов. Это вполне предсказуемая проблема, и на протяжении многих лет международное сообщество прилагает усилия по оказанию помощи в наращивании потенциала государственно-частного партнерства на развивающихся рынках, к каким относится и Российская Федерация. Поиск путей привлечения инвестиций частного сектора в сферу НХП с помощью разумной, последовательной и устойчивой политики государственного сектора должен стать одним из основных направлений деятельности органов государственной власти в России.

Термин «государственно-частное партнерство» описывает круг возможных отношений между государственными и частными организациями в контексте развития предпринимательской деятельности и оказания необходимых государственных услуг. ГЧП представляют собой рамочную основу, которая при вовлечении частного сектора признает и структурирует роль органов государства в обеспечении выполнения социальных обязательств и достижения успешных отраслевых реформ и государственных инвестиций.

Реализация ГЧП в сфере НХП представляет собой 
долгосрочные договорные партнерские отношения между государственным и частным сектором. ГЧП может включать в этой сфере финансирование, проектирование, строительство, эксплуатацию и/или техническое обслуживание определенных объектов и предоставление услуг частным сектором, которые обычно закупаются и предоставляются государственным сектором. Помимо этого, соглашение о ГЧП может включать в себя и ряд условий, связанных с передачей сторонами соглашения «результатов интеллектуальной деятельности и (или) средств индивидуализации, необходимых для исполнения соглашения» $[1$, ст. 12]. Следовательно, модель ГЧП дает преимущества для обеих сторон при условии эффективного сочетания целей государственного и частного секторов. Важно учитывать обстоятельства, при которых ГЧП может быть наилучшим методом развития предпринимательской деятельности в отрасли НХП по сравнению с другими традиционными методами государственных закупок.

В настоящее время механизм ГЧП уже доказал свою эффективность в основном в инфраструктурных проектах: транспорт, дорожное строительство водоснабжение и т.п. Так, Республика Бурятия использует механизм ГЧП в сфере туризма и переработки отходов лесной промышленности. В частности, основанием для этого стало Постановление Правительства Российской Федерации от 3 февраля 2007г. № 68 «О создании на территории муниципального образования «Прибайкальский район» Республики Бурятия особой экономической зоны туристско-рекреационного типа». Причем заинтересованность регионов в его реализации проявляется и на законодательном уровне. Следует выделить принятие еще в 2008г. Закона Республики Алтай № 15-Р3 «Об основах государственно-частного партнерства», целью которого стало создание необходимых условий для развития государственно-частного партнерства при реализации ключевых региональных направлений развития как экономики, так и социальной сферы.

26 мая 2010 г. был принят Закон Краснодарского края № 1989-К3 «О государственной политике Краснодарского края в сфере государственно-частного партнерства», благодаря которому были определены основные направления государственной политики Краснодарского края в сфере государственно-частного партнерства. 22 июля 2010г. и в Ростовской области был принят Закон № 448-3С «Об основах государственно-частного партнерства», приоритетом которого стало обеспечение стабильных условий развития различных форм ГЧП и повышения уровня жизни населения. В 2012г. 29 февраля 2012г. в Республике Бурятия был принят закон «О государственно-частном партнерстве в Республике Бурятия», который позволил сформировать правовую основу, определить цели и принципы реализации государственно-частного партнерства и ряд других моментов в республике.

Причиной реализации ГЧП в сфере НХП можно признать постоянную и растущую необходимость органов государственной власти в изыскании достаточного финансирования для развития и поддержания производственных мощностей народных художественных промыслов или оказания сопутствующих государственных услуг, необходимой для поддержки организаций или мастеров НХП. При этом эффективное использование ограниченных государственных ресурсов является важнейшей задачей для органов власти [7, с 24].

В настоящее время есть примеры успешной реализации механизма ГЧП в культуре. Так, проект ГЧП «Усадьба Аигиных» был реализован в рамках Губернаторской программы «Усадьбы Подмосковья» [5] и на основе Постановления Правительства Московской области от 13.05.2013 № 297/17 «Об утверждении порядка установления льготной арендной платы и ее размеров в отношении объектов культурного наследия, находящихся в собственности Московской области» [3] .

Существующие примеры применения ГЧП в сфере культуры подтверждают, что эффективно организованное ГЧП в состоянии мобилизовать ранее неиспользованные ресурсы из городских, региональных или международных источников частного сектора, который ищет инвестиционные возможности.

Согласно существующей практике ГЧП, возможно выделить две основные группы мер поддержки подобного рода партнерств, существующих в мире: финансовые меры и нефинансовые меры поддержки. В частности, Всемирный банк [13] выделяет следующие меры финансовой поддержки: меры прямого финансирования; установление льготного порядка или полного освобождения от уплаты налогов или иных форм государственных обязательств; осуществление субсидирования тарифных ставок, выдача займов, введение повышенных тарифов для отдельной категории или всех потребителей. В свою очередь мерами нефинансовой поддержки ГЧП в большинстве случаев являлись консультативно-методическая активность и информационно-аналитическая поддержка частных партнеров и концессионеров.

Применительно к сфере культуры к основным формам реализации проектов ГЧП М.С. Нагорная и В.В. Шевцова отнесли «концессионные соглашения и контракты жизненного цикла, а также менее масштабные по вложениям инвестиционно-девелоперские проекты; системные социокультурные практики; событийные проекты; спонсорские проекты, инициированные государством при поддержке средств бизнеса» [9, с.35]. Государственный сектор сохраняет только свою регулирующую и надзорную функцию (например, установление стандартов 
на осуществляемые работы или оказываемые услуги и надзор за их соответствием). С другой стороны, частный сектор может взимать плату за оказанные услуги непосредственно с конечного потребителя (и нести риск рыночного спроса) или с государственного сектора в виде арендной платы и тому подобного (и нести риск доступности объекта).

Частный сектор обычно также берет на себя такие задачи, как техническое обслуживание эксплуатация и аналогичные задачи, а также берет на себя риски, с которыми частный сектор может справиться лучше. Это должно обеспечиваться, даже если государственные органы продолжают нести часть инвестиционных или операционных расходов, поскольку их обязательства по расходам, скорее всего, будут целевыми, ограниченными и структурированными в рамках рационализации общей стратегии государственного финансирования. Однако правильно реализованный подход позволяет привести к снижению совокупного денежного потока затрат государства, а также к улучшению и снижению стоимости обслуживания потребителей [10, с. 44].

Государственно-частное партнерство предопределяется заключением договора между государственными органами и частным сектором, который не имеет своей целью предоставление государственных услуг, задачей которого является приватизация общественных благ или поощрение прямых инвестиций в рыночно ориентированные проекты. Реализация конкретной сделки ГЧП особенно в сфере НХП может потребовать реализацию определенных шагов для поддержки нового распределения секторальных ролей, таких как принятие законов, подзаконных актов или создание отдельных органов управления. По существу, пересмотр регулятивных механизмов в сфере НХП применительно к конкретному проекту ГЧП является крайне важным для успеха партнерства. Как справедливо отметили депутаты Государственной Думы ФС РФ: «Заставить российский бизнес быть социально ответственным невозможно, можно лишь заинтересовать, показав явное преимущество и хотя бы отдалённую перспективу» [8].

Органы государственной власти могут рассматривать ГЧП в качестве катализатора, провоцирующего более широкое обсуждение и приверженность программе реформирования отрасли НХП, одним из компонентов которой является ГЧП. Ключевой вопрос - это всегда реструктуризация и уточнение ролей внутри данной сферы. Реформа программы развития НХП, включающая ГЧП, дает возможность пересмотреть назначение роли субъектов предпринимательства, вовлеченных в эти процессы для устранения любых потенциальных конфликтов и рассмотрения частного субъекта ГЧП в качестве возможного участника сферы НХП.
Подготовка и внедрение ГЧП в отрасль НХП - это длительный и дорогостоящий процесс. Следовательно, модель ГЧП необходимо использовать только в том случае, если распределение риска обеспечивает государственному сектору более низкие совокупные издержки в течение всего согласованного срока реализации проекта (большее соотношение цены и качества) или доступ к знаниям, навыкам и тому подобное, которые в противном случае были бы недоступны, и которые вносят значительный вклад в уровень оказанных государственных услуг. Выполнение указанных критериев означает проведения ряда предварительных исследований (например, маркетинговые исследования, работы по выбору объектов, технико-экономические обоснования, вопросы интеллектуальной собственности и т. д.), а также критерии обоснованности использования модели ГЧП применительно к конкретным видам и деятельности НХП.

Положительным моментом использования ГЧП в сфере НХП состоит в том, что партнерство открывает возможности для частных инвестиций, которые могут привести к реализация проектов, которые в противном случае, исходя из классического (бюджетного) финансирования, не были бы возможны или потребовали гораздо более длительных периодов времени для реализации, что часто бывает недопустимо, когда определенные государственные услуги или их адекватный уровень должны быть обеспечены оперативно [12, с. 30]. ГЧП позволяют частному сектору использовать финансовые, деловые и другие виды знаний и навыков, а также инновационный предпринимательский подход в реализации и управлении проектами, который часто является основной причиной для использования модели ГЧП. Кроме того, касательно вопроса интеллектуальной собственности в сфере НХП, ГЧП позволяет передавать право использования (исключительного права) в отношении объектов интеллектуальной собственности публичным образованием или государственным учреждением частному лицу.

Однако стороны частного сектора заключают инвестиционные или контрактные соглашения с четкой целью максимизации прибыли, которая генерируется, в значительной степени, за счет увеличения эффективность инвестиций и текущих операций. Если ГЧП организовано таким образом, чтобы позволить стороне преследовать эту цель, скорее всего, повысится эффективность реализуемых в его рамках работ или услуг. Повышение эффективности услуг и операций также повышает вероятность того, что эти услуги являются качественными и предоставляемыми по доступным ценам. Как свидетельствует практика, эффективные ГЧП способствуют тому, что государственный и частный секторы имеют определенные преимущества по отношению друг к другу при решении конкретных задач. Это может найти свое отражение в таких механизмах как защита объек- 
тов интеллектуальной собственности (товарных знаков - известных брендов Семеновская Хохлома, Павлово-Посадские платки, Палех, Гжель) в борьбе с контрафактной продукцией, включая работу таможни (Евразийская таможня), консолидацию работы на рынках сбыт продукции, централизованную подготовку кадров и т.д.

В частности, возможность применения интеллектуальной собственности в рамках реализации ГЧП в рассматриваемой сфере обладает значительным потенциалом. Так, Федеральный закон от 13.07.15 Ф3-224 «О государственно-частном партнерстве» прямо определяет возможности применения в хозяйственном обороте результатов ИС на основе механизма использование и распоряжение исключительными правами на них. Кроме того, возможность реализации таких отношений на основе лицензионного договора, договора отчуждения и договора коммерческой концессии [4, с. 320] представляется возможной и в рамках государственно-частного партнерства.

Следует учитывать, что структура партнерства должна исходить из адекватного распределения правовых и экономических рисков между партнерами и таким образом минимизировать их затраты. Поэтому одна из главных проблем при внедрении ГЧП заключается в правильном определении прав и обязанностей для всех его участников. Не исключено, что это может потребовать подготовки на региональном или местном уровне правовых актов, определяющих механизмы регулирования определенных отношений в рамках ГЧП. При этом применительно к сфере НХП, реализация ГЧП может быть успешной только в том случае, если будет обеспечено участие представителей гражданского общества региона или определенной местности.

Можно выделить ряд моментов, которые позволят которые перейти от теоретического осмысления к реальной реализации и достижению поставленных целей с использованием ГЧП в предпринимательской деятельности в сфере НХП:

- ГЧП в НХП нуждаются в надежной и долгосрочной поддержке государственного сектора. Органы власти иногда прибегают к ГЧП для противодействия финансовым ограничениям, рассматривая ГЧП как «забалансовые». Какова бы ни была причина для внедрения ГЧП, проект должен обеспечивать соотношение цены и качества в течение всей жизни по сравнению с альтернативой закупкам в государственном секторе;

- устойчивое состояние основных источников финансирования ГЧП имеет решающее значение для эффективной его реализации в сфере НХП. Для большинства видов ГЧП существуют, по существу, только два источника финансирования полной стоимости партнерства: либо из бюджета через общее налогообложение, либо непосредственно от пользователей определенного актива. Часто требуется некоторое сочетание этих двух источников финансирования. Поэтому платежеспособность государственных органов является обязательным условием при разработке ГЧП;

- значим фактором развития механизма ГЧП в сфере НХП, является использование местного потенциала частного сектора в сделках ГЧП, особенно в местах традиционного бытования народных промыслов. В долгосрочной перспективе потенциал местных участников ГЧП должен быть расширен для расширения инвестиций в ГЧП;

- индустрия НХП нуждается в дальнейшем развитии финансовых продуктов для повышения кредитоспособности ГЧП. Многие регионы не имеют суверенного рейтинга инвестиционного уровня, что затрудняет финансирование большинства проектов для широкого круга потенциальных институциональных инвесторов, которые являются логичным выбором в рамках сценария рефинансирования и даже в некоторых случаях для новых проектов. В этих условиях хорошо продуманные рыночные механизмы повышения кредитоспособности регионов имеют реальные перспективы развития НХП на основе реализации механизма ГЧП.

Успешный опыт создания государственных корпораций в определенных отраслевых сегментах обеспечил необходимую конкурентоспособность и устойчивость этих отраслей. Создание специализированной государственной корпорации по НХП может стать эффективным инструментом поддержки и развития предприятий народных художественных промыслов, которые вошли бы в состав корпорации. По организационно-правовой форме - это некоммерческая организация, определяющая основные механизмы деятельности корпоративной группы компаний.

Для создания государственной корпорации НХП необходимо подготовить и утвердить ряд нормативных актов на федеральном и региональном уровнях. В первую очередь необходимо разработать и утвердить программу развития специализированной корпорации, в которой важно отразить основополагающие принципы взаимодействия предприятий, входящих в корпорацию в организационном плане (создание наблюдательного совета, совета директоров, разработку устава и положения). В программе развития основными аспектами должны быть пункты, связанные с коллективными действиями по защите объектов интеллектуальной собственности, продвижению продукции на внутренний и внешний рынки, подготовке специалистов, созданию единой электронной базы технологий, участию в международных выставочно-конгрессных мероприятиях и т.д.). 
Таким образом, гЧП в новых формах могло бы существенно изменить состояние в отрасли НХП, где основной принцип предлагаемого государственно-частного партнерства - это централизация усилий по поддержке отрасли, которая включает аккумуляцию финансовых ресурсов из государственных и частных источников, охрану на государственном уровне объектов интеллектуальной собственности и защиту от контрафактной продукции.

ЛИТЕРАТУРА

1. Федеральный закон «0 государственно-частном партнерстве, муниципально-частном партнерстве в Российской Федерации и внесении изменений в отдельные законодательные акты Российской Федерации» от 13.07.2015 № 224-Ф3 // Российская газета. № 156, 17.07.2015.

2. Федеральный закон «0 народных художественных промыслах» 0т 06.01.1999 N 7-Ф3 // Российская газета. № 7, 15.01.1999.

3. Постановление Правительства МО от 13.05.2013 № 297/17 «0б утверждении порядка установления льготной арендной платы и ее размеров в отношении объектов культурного наследия, находящихся в собственности Московской области» (вместе с «Перечнем объектов культурного наследия Московской области, находящихся в неудовлетворительном состоянии и подлежащих передаче в аренду»). [Электронный pecypc]. - URL:http://mosobl. elcode.ru/page.aspx?130762

4. Бодрунов С.Л., Лопатин В.Н. Стратегия и политика реиндустриализации для инновационного развития России: монография / Институт нового индустриального развития (ИНИР). СПб., 2014. - 486 с.

5. Губернаторская программа «Усадьбы Подмосковья». [Электронный ресурс]. - URL: http://mosreg.ru/seychas-vrabote/gosudarstvennye-programmy/ programma-usadby-podmoskovya

6. Казаков А.О. Состав участников государственно-частного партнерства, муниципально-частного партнерства // Пробелы в российском законодательстве. - 2015. - № 5. - С. 92-96.

7. Макаров И.Н. Государственно-частное партнерство сегодня современная экономика: регулирование и партнерство // Российское предпринимательство. - 2009. - № 8-2. - С. 22-28.

8. Материалы парламентских слушаний. Парламентский час от 25.06.2017. [Электронный ресурc]. - URL: https://www.youtube.com/watch?v=2-_4rnXLIrM

9. Нагорная М.С., Шевцова В.В. Практика государственно-частного партнёрства в сфере сохранения культурного наследия России // Управление в современных системах. - 2018. - №1(17).

10. Саницкий Д.И. Государственно-частное партнерство в России: сущность и условия развития // Финансовое право. - 2016. - № 7. - С. $44-47$.

11. Серебрякова Т.А. К вопросу о формировании и развитии нового правового института - государственно-частное партнерство (муниципально-частное партнерство) // Журнал юридических исследований. - 2017. Т. 2. - № 1. - С. 132-143.

12. Чумаков И.И. Государственно-частное партнерство как основная форма партнерства государства и бизнеса // Актуальные проблемы и перспективы развития экономики: российский и зарубежный опыт. - 2017. - № 11. - С. 29-32.

13. Public-Private Partnerships Reference Guide. Version 2.0. World Bank Group. 2014.

(с) Жигалова Ирина Валерьевна (Zhigaloval@gorodissky.ru).

Журнал «Современная наука: актуальные проблемы теории и практики» 